\title{
Above- and below-ground biomass, surface and volume, and stored water in a mature Scots pine stand
}

\author{
J. Urban · J. Čermák $\cdot$ R. Ceulemans
}

Received: 2 April 2014/Revised: 15 July 2014/ Accepted: 28 July 2014/Published online: 9 August 2014

(C) The Author(s) 2014. This article is published with open access at Springerlink.com

\begin{abstract}
This study describes the amount and the spatial distribution of the above- and below-ground tree skeletondefined as the woody structure of stem, branches and rootsin a mature Scots pine (Pinus sylvestris L.) stand in Belgium. Tree skeleton data were linked to the respective needle area, and as such, this work provides the background framework for modeling the tree hydraulic architecture and the carbon balance of the forest stand. Using validated allometric equations, we were able to calculate the amount of the volume, of the biomass and of the corresponding surface areas of individual trees in the stand. Total woody biomass of the 66-year-old forest stand was $155 \mathrm{Mg} \mathrm{ha}^{-1}$, i.e., $126 \mathrm{Mg} \mathrm{ha}^{-1}$ above ground and $29 \mathrm{Mg} \mathrm{ha}^{-1}$ below ground. The total bio-volume of the woody mass of the stand was $314 \mathrm{~m}^{3} \mathrm{ha}^{-1}$. The highest fraction of this value was the stem bio-volume, i.e., $236 \mathrm{~m}^{3} \mathrm{ha}^{-1}$ or $75 \%$ of the total. The total volume of all roots was $57 \mathrm{~m}^{3} \mathrm{ha}^{-1}(18 \%$ of the total volume), and the volume of branches was $20 \mathrm{~m}^{3} \mathrm{ha}^{-1}$ (7 \% of the total volume). The surface area of the roots ranged from $38,000 \mathrm{~m}^{2} \mathrm{ha}^{-1}$ in the winter to $68,000 \mathrm{~m}^{2} \mathrm{ha}^{-1}$ in the spring. The surface area of the stems was $2,700 \mathrm{~m}^{2} \mathrm{ha}^{-1}$, and the surface area of all branches reached $4,400 \mathrm{~m}^{2} \mathrm{ha}^{-1}$. The total above-ground water storage in the xylem was
\end{abstract}

Communicated by Agustín Merino.

J. Urban $(\bowtie) \cdot J$. Čermák

Faculty of Forestry and Wood Technology, Mendel University in

Brno, Zemedelska 3, 61300 Brno, Czech Republic

e-mail: josef.urban@email.cz; josef.urban@mendelu.cz

J. Čermák

e-mail: cermak@mendelu.cz

R. Ceulemans

Department of Biology, University of Antwerp,

Universiteitsplein 1, 2610 Wilrijk, Belgium
$94 \mathrm{~m}^{3} \mathrm{ha}^{-1}$ (or $9.4 \mathrm{~mm}$ ), while the accessible stored water was $2 \mathrm{~mm}$ of that quantity. A comparative analysis of the biometric parameters showed the balance between the different functionally connected, operational surface areas of the trees. The needle surface area was similar to the root surface area and in the same order of magnitude as the surface area of woody cambium. The results allow to link water uptake with transpiration and assimilation with respiration.

Keywords Allometry - Biomass - Carbon budget $\cdot$ Huber value $\cdot$ Respiration $\cdot$ Sap flow $\cdot$ Water balance $\cdot$ Pinus sylvestris

\section{Introduction}

Forests contain about $90 \%$ of the carbon stored in the terrestrial vegetation and account for $40 \%$ of the carbon exchange between the atmosphere and the terrestrial biome (Schlesinger 1997). Forest stands contribute to the terrestrial carbon balance in two different ways. First, forest stands are the principal pools of the stored carbon. It is therefore of interest to quantify tree biomass and its increment to enable the quantification of the carbon pool size. Secondly, forest trees exchange carbon with the atmosphere, not only through the uptake of carbon in photosynthesis, but also through the release of carbon dioxide via the respiration of living cells. The amount of carbon released by the woody skeleton (stem and branches) is usually quantified on a surface area basis (Edwards and Hanson 1996; Damesin et al. 2002; Kim et al. 2007; Acosta et al. 2008). For a proper extrapolation to the tree and the stand levels, the tree surface area should be known. Scots pine (Pinus sylvestris L.) is the most widely spread pine 
species across Eurasia, covering $24 \%$ of Europe's forested area (Stanners and Bourdeau 1995) and growing in a wide range of ecotypes (Richardson 1998). Scots pine stands are thus an important factor affecting the carbon and water balances in Europe and Asia (Richardson 1998; Poyatos et al. 2007). Although there is a good knowledge of the stems of Scots pine (e.g., Claesson et al. 2001; Landsberg et al. 2005), much less is known about the surface area and the biomass of branches and roots.

The vertical distribution of roots and branches plays an important role in the competitiveness of an individual tree (Stoll and Schmid 1998). The branches hold the needles, exposing them to incoming radiation, and thus affect photosynthesis and transpiration of the individual tree (Sala and Tenhunen 1996; Peters et al. 2008). With their high surface area, branches significantly contribute to the overall tree respiration (Damesin et al. 2002). Therefore, an optimal needle to branch (and stem) surface area improves the carbon economy of the tree. Similarly, the rate and the structure of colonization of the soil by roots affect both water and nutrient uptake. Usually, most of the roots grow in the topsoil layers, exploiting the most fertile soil horizons and acquiring rain water (Jackson et al. 1996; Monserud et al. 1996; Janssens et al. 1999; Xiao et al. 2003; Konopka et al. 2005, 2006). However, in sites with easily accessible groundwater and low precipitation, a significant fraction of the roots grow in deeper soil layers, as, e.g., observed in Scots pine (Nadezhdina et al. 2007; Čermák et al. 2008a) and in oak trees (Vyskot 1976; Tatarinov et al. 2008), among others. The distribution of biomass and biosurface area (i.e., the surface area of the plant/tree parts) is similar in roots and branches: The highest amount of biomass is located in the coarse roots and in the coarse branches, whereas the highest surface area is generally found in the fine roots and in the thin branches (Helmisaari et al. 2002).

Tree allometry reflects the environmental conditions and stand properties as well as individual tree status - especially age, social position and tree health (Cannell 1982; Bartelink 1997; Konôpka et al. 2010; Wang et al. 2011; Poorter et al. 2012). Theoretically, allometric equations describing tree dimensions are affected by the physiological requirements of the tree; i.e., form and function are related. The most important of these requirements are water transport, light interception, and mechanical support against gravity or wind (Niklas 1994). The present allometric study provides the necessary background information and knowledge for more detailed studies on water relations of Scots pines of different social positions. From the hydraulic point of view, a tree may be viewed as a network of interconnected pipes (Zimmerman 1983). According to the "pipe model theory" (Shinozaki et al. 1964), the quantity of roots is proportional to the conductive stem cross-sectional area of a tree (i.e., sapwood), while the sapwood area is linked to the amount of foliage. Any disproportion in this balance will affect tree function. For example, larger crowns relative to the sapwood area result - if other tree parameters of the overall hydraulic conductivity remain the same-in lower water potentials and in a higher risk of cavitation (Maherali and de Lucia 2000; Cochard 2006; Ogasa et al. 2013). The Huber value (HV, Huber 1928; Tyree and Ewers 1991)_defined as the sapwood area supporting a unit amount of foliage-is therefore a good measure of tree adaptation to the environment and of the susceptibility of a tree to stress (e.g., Berninger et al. 1995; Poyatos et al. 2007, Martínez-Vilalta et al. 2009). Sapwood water storage is a key feature that helps the tree to cope with diurnal peaks in water demand as well as with a longer drought stress. A considerable amount of water for the daily transpiration is supplied from the stored water (Čermák et al. 1982; Goldstein et al. 1998; Zweifel et al. 2000; Čermák et al. 2007; Urban et al. 2013). Therefore, this paper also describes the amount of available water storage in the skeleton organs.

The aims of the current study were as follows: (1) to describe the amount and the spatial distribution-vertical, radial as well as within individual trees-of the skeleton (i.e., the tree structure consisting of stem, branches and roots) of a mature Scots pine stand in terms of their biomass, volume, surface area and water storage; (2) to describe the overall crown and canopy architecture, as well as the root geometry; (3) to provide and evaluate the necessary scaling-up tools and allometric relations so that these can be applied to various parameters and processes of main interest to canopy carbon and water fluxes; and (4) to describe the ecological consequences of the skeleton parameters linked to the other functional tree organs. As such, this study extends a previous paper (Čermák et al. 1998) covering the needle and coarse root distribution of the same set of Scots pine trees. In this study, 'skeleton' is defined as the structural part of the tree, i.e., the branches, the stem and the coarse roots.

\section{Materials and methods}

Experimental site-location, climate and soil

The study was performed at the experimental plot of a Scots pine (Pinus sylvestris L.) forest in Brasschaat, Campine region of the province of Antwerp, Belgium $\left(51^{\circ} 18^{\prime} 33^{\prime \prime} \mathrm{N}\right.$ and $4^{\circ} 31^{\prime} 14^{\prime \prime} \mathrm{E}$, altitude $16 \mathrm{~m}$, orientation N.N.E.). This forest is part of the regional forest 'De Inslag' (parcel no. 6, Flemish Region) located nearly $15 \mathrm{~km}$ northeast from Antwerp. The site is almost flat (slope $1.5 \%$ ) and belongs to the plateau of the northern lower plain basin of the Scheldt River. Soil characteristics are as 
follows: (1) moderately wet sandy soil with a distinct humus and/or iron B-horizon (psammenti haplumbrept in the USDA classification, umbric regosol or haplic podzol in the FAO classification); (2) very deep (1.75-2.25 m) eolian sand (Dryas III), somewhat poorly drained (neither receiving nor shedding water); and (3) rarely saturated but moist with rapid hydraulic conductivity for all horizons (Baeyens et al. 1993; Van den Berge et al. 1992). The groundwater depth normally ranges between 1.2 and $1.5 \mathrm{~m}$ and might be lower due to non-edaphic circumstances. Human impacts mainly include deep (up to $45 \mathrm{~cm}$ ) forest tillage in the past. The occurrence of a Rhododendron ponticum (L.) shrub in the understorey layer causes (probably also because of allelopathic effects) an unfavorable O-litter characterized by very low biological activity. A mycelium and many ants are present in the litter layer. The climate of the Campine region is moist subhumid (C1), rainy and mesothermal (B'1) (Köppen 1936). The Campine region has a temperate maritime climate with a mean (over 28 years) annual temperature of $9.8{ }^{\circ} \mathrm{C}$ and a mean annual precipitation of $767 \mathrm{~mm}$. The mean annual potential evapotranspiration is $670 \mathrm{~mm}$ (Carrara et al. 2003).

\section{Forest stand}

The original climax vegetation (natural forest) in the area was a Querceto-Betuletum (Tack et al. 1993). The studied pine stand was planted in 1929 . The stocking density was 1,390 trees $\mathrm{ha}^{-1}$ in 1980 , decreasing to 899 trees ha $^{-1}$ in 1987, 743 trees ha ${ }^{-1}$ in 1990 and 716 trees ha ${ }^{-1}$ in 1993. Due to windfall in 1994, a remaining 542 trees ha ${ }^{-1}$ were still present in 1995 . The most recent forest inventory dated from spring 1995, including the frequency distribution of stem diameter at breast height (DBH at $1.30 \mathrm{~m}$ above the ground), tree height to the top and to the basis of the crown (i.e., the lowest green whorl). All the forest inventory data were collected for the entire area of the experimental plot (1.996 ha, Čermák et al. 1998)). The sparse pine canopy allowed a rather dense vegetation of a few understorey species as Prunus serotina (Urban et al. 2009) and Rhododendron ponticum (Nadezhdina et al. 2004) which were partially removed in 1993 until a ground cover of about $20 \%$ of the area. The herbaceous layer was composed of a dominant grass (Molinia caerulea, covering about $50 \%$ of the area), and some mosses (Hypnum cupressiforme and Polytrichum commune) that created a compact layer in about $30 \%$ of the surface area.

Tree sampling

The stand was measured in diameter at breast height $(\mathrm{DBH})$ classes of $2-\mathrm{cm}$ resolution. The number of trees in each DBH class was recorded, and these numbers were used in up-scaling calculations. Six sample pine trees were selected for the harvest and for the destructive measurements as representatives for the entire stand. The selection of these trees was based on their basal area using the technique of the quantils of the total (Čermák and Kučera 1990; Čermák and Michalek 1991). Biometric data were measured on these six sample trees, i.e., stem diameter at breast height including the bark (DBH), stem diameter below the green crown including the bark (DGC), the corresponding bark thickness, total tree height, height of the base of the crown and crown projected area. In the summer of 1995, each sample tree was cut and slowly put on the ground, using ropes, to prevent significant breakage of branches. For three sample trees-with a DBH of 21.4, 28.5 and 40.6-a suppressed, a co-dominant and a dominant tree, respectively-the spatial distribution of all branches and needles within the crown was analyzed in detail using the 'cloud' technique (Čermák 1990; Čermák et al. 1998). Only the total amounts of needles and of branches were assessed in the other three sample trees. Needle and (partially) root distribution of the same set of trees were described previously (Čermák et al. 1998).

Additional measurements on a set of seven randomly chosen trees were taken in the same forest stand in the same year (August 1995) to describe properties of coarse roots. Stem diameters of these seven trees ranged from 19 to $31 \mathrm{~cm}$ with a mean of $26 \mathrm{~cm}$. After a rough excavation from the sandy soil, the mean diameter of the root system, the total rooting depth, the mean length and diameter of the main roots were measured. The below-ground part of the stump was not included into the calculations of the coarse root biomass. To get a crude estimate of the total volume and the dry mass of the root systems, the volume to dry mass ratio of the base of the stem was also used for the roots. The upscaling of the biometric root parameters from the individual trees to the entire stand was approached in the same way as for the above-ground biomass. Data related to the fine and small root biomass of the investigated forest site were obtained and reported by Janssens et al. (1999) for the spring and by Xiao et al. (2003) for the winter, thus, respectively, representing the maximum and the minimum amounts of root biomass. These data were obtained by the method of soil coring with subsequent washing and scanning. The surface area and the dry root biomass were estimated. Three diameter classes of fine and small roots were distinguished, i.e., less than 1, 1-2 and 2-5 $\mathrm{mm}$. The vertical profile of the root distribution was described in $20 \mathrm{~cm}$ steps to the depth of $80 \mathrm{~cm}$. In analogy with the leaf area index (LAI) of the needles, the total root surface area was also presented as the root area index (RAI). RAI $\left(\mathrm{m}^{2} \mathrm{~m}^{-2}\right)$ was calculated as the surface area of the roots of all size classes in a particular forest area divided by the ground surface area. 
Biomass, volume, surface area and amount of water

In general, the same approach was applied as was used for the description of the needle distribution reported previously (Čermák et al. 1998). For each branch, the following parameters were measured with a taper, a caliper and a protractor, respectively: The branch diameter at $10 \mathrm{~cm}$ from the main stem as well as just below the green part with needles; the bark thickness; the branch orientation (azimuth); the vertical angles of the branch to the main stem and to the center of the leaf cluster- 'cloud'; the total branch length; and the length up to the green part of the branch. Furthermore, all branches were cut into pieces and separated into three categories, i.e., large branches (diameter of the branch at the point of cutting larger than $2.5 \mathrm{~cm}$ ), small branches (diameter $\leq 2.5 \mathrm{~cm}$ ) and shoots (maximum 3-year-old branches, actually holding the needles). Unless further specified otherwise, all shoots were assessed together with the small branches. The main stem was divided into sections with a length of $20 \mathrm{~cm}$. The mean diameter and the bark thickness were measured for each section. The volume was calculated from the length and the mean diameter of the stem sections. From each section, samples of the wood (side length of the block taken from the stem was $5 \mathrm{~cm}$ ) were collected for the quantification of the amount of water and of air.

Fresh weight of the wood samples collected from the stem and from the branches was measured in the laboratory. All samples taken in the forest were immediately wrapped in aluminum foil and stored within a polystyrene box above ice (in a plastic bag). Manipulations of the samples were done in a cool cellar room with high air humidity. Dry mass of each wood sample was estimated after $48 \mathrm{~h}$ at $105{ }^{\circ} \mathrm{C}$ in a drying oven. Wood samples from the branches were dried as one piece. The fresh weight $\left(W_{\mathrm{f}}\right)$, the dry weight $\left(W_{\mathrm{d}}\right)$, the volume of air and of water were calculated for each sample according to Eqs. 1 and 2. Wood samples from the stem were divided into pieces (segments) of $5 \mathrm{~mm}$ length. Volume $(V)$, fresh and dry weight were measured for each piece, to allow measurements of the water content in the radial direction. The wood density $\left(\rho_{\mathrm{w}}\right)$, the air and water volumes and the mass of the water (relative water content, RWC) were calculated for each of the pieces (segments) according to the following equations:

$$
\begin{aligned}
& \rho_{\mathrm{w}}=W_{\mathrm{d}} / V \\
& \mathrm{RWC}=100 \cdot\left(W_{\mathrm{f}}-W_{\mathrm{d}}\right) / W_{\mathrm{d}}
\end{aligned}
$$

Depth of the sapwood was estimated from the drop in the radial profile of the water content, typical for some tree species including Scots pine (Kravka et al. 1999; Gartner and Meinzer 2005). The amount of utilizable water at the time of sampling was measured as the difference between the RWC in the sapwood and in the heartwood following the procedure of Kravka et al. (1999). Two mean values of the wood density, one for the sapwood and one for the heartwood, were used in further calculations. The volume of the skeleton was calculated for each branch and for each stem separately from the measured wood density. The amount of water was calculated from the volume of the sapwood, of the heartwood and of the branches, and from the corresponding volumetric water content.

Branches were divided into the sections of various lengths, depending on their shape. The surface area $(A)$ of each branch was estimated from mean diameter $(d)$ and length $(l)$ of a section according the formula:

$A=\pi \cdot d \cdot l$

Surface area of the stem was calculated for the different sections from the mean diameter and the length of each section (Eq. 3) and then cumulated toward the entire stem. The surface area of the stem and of the branches was calculated both with and without bark. The surface area without bark referred to as the cambium surface area. To allow comparisons with other indices (as LAI), the cambium surface area was expressed as cambium area index (CAI). CAI $\left(\mathrm{m}^{2} \mathrm{~m}^{-2}\right)$ was calculated as the total cambium surface area in the forest site divided by the respective ground area (Honzová and Čermák 2011).

\section{Vertical and radial distribution of skeleton parameters}

The vertical and the radial distributions of the stem and of all branches were destructively estimated on the harvested trees using the 'cloud' technique (Čermák 1990; Čermák et al. 1998). The position of the branches in relation to the stem was characterized as the location (or position) in a grid of cells surrounding the stem. Each of the trees was positioned in a theoretical grid (network) of cells (of $0.2 \mathrm{~m}$ $* 0.2 \mathrm{~m} * 0.2 \mathrm{~m}, 125$ cubical cells per $\mathrm{m}^{3}$ ) containing different fractions of the entire tree skeleton. These cells were projected on a vertical and on a horizontal plane with a $0.2 \mathrm{~m} * 0.2 \mathrm{~m}$ matrix $\left(25\right.$ squares per $\mathrm{m}^{2}$ ). Every cloud of the tree or the branch was characterized by a certain number of cells (squares) covering the area of the projection of the cloud. The total dry mass, respectively the surface area divided by the cell volume, represented the actual spatial skeleton density $\left(\rho_{\mathrm{c}}\right)$. The sum of all $(\mathrm{k})$ clouds represented the total dry mass of the skeleton $\left(M_{\mathrm{L}}\right)$, the total skeleton surface area $\left(A_{\mathrm{L}}\right)$, the skeleton volume $\left(V_{\mathrm{L}}\right)$ and the water storage $\left(W_{\mathrm{L}}\right)$ of the tree. The total dry mass $\left(M_{\mathrm{L} . \mathrm{k}}\right)$, respectively the surface area of the branch $\left(A_{\mathrm{L} . \mathrm{k}}\right)$, the skeleton volume $\left(V_{\mathrm{Lk}}\right)$ and the water storage $\left(W_{\mathrm{Lk}}\right)$ divided by the number of cells-separately for the vertical and horizontal projection ( $\mathrm{s}_{\mathrm{kv}}$ and $\left.\mathrm{s}_{\mathrm{kh}}\right)$ - 
Table 1 Allometric relationships for volumes, surface areas and water content—all assessed at breast height diameter (DBH, $\mathrm{cm})$-of the above-ground skeleton

\begin{tabular}{|c|c|c|c|c|c|c|c|c|}
\hline \multirow[t]{2}{*}{ Regressions } & \multirow[t]{2}{*}{$R^{2}$} & \multicolumn{3}{|c|}{ Generalized trees $(\mathrm{DBH}, \mathrm{cm})$} & \multicolumn{3}{|c|}{ Sample trees $(\mathrm{DBH}, \mathrm{cm})$} & \multirow[t]{2}{*}{ Amount per ha } \\
\hline & & 22 & 28 & 34 & 21.4 & 28.5 & 40.6 & \\
\hline
\end{tabular}

Stems

Surface area of cambium

Volume without bark $\left(\mathrm{m}^{3}\right)$

Surface outside bark $\left(\mathrm{m}^{2}\right)$

Volume including bark $\left(\mathrm{m}^{3}\right)$

Volume of bark $\left(\mathrm{m}^{3}\right)$

Biomass of bark $(\mathrm{kg})$

Volume of heartwood $\left(\mathrm{m}^{3}\right)$

Volume of sapwood $\left(\mathrm{m}^{3}\right)$

Total dry wood biomass $(\mathrm{kg})$

Sapwood depth (cm)

Heartwood biomass $(\mathrm{kg})$

Sapwood biomass (kg)

Water content in sapwood $(\mathrm{kg})$

Water content in heartwood $(\mathrm{kg})$

$0.13 x^{1.10}$

$0.00030 x^{2.13} \quad 0.92$

$0.12 x^{1.15} \quad 0.92$

3.90

0.22

5.08

0.36

$0.00030 x^{2.16} \quad 0.91$

4.20

5.54

$2 E-06 x^{2.99} \quad 0.87$

0.24

$0.00089 x^{2.99} \quad 0.87$

$1 E-07 x^{3.87} \quad 0.99$

$0.00065 x^{1.90} \quad 0.88$

$0.18 x^{2.13}$

$1.7 x^{0.42}$

0.92

$6 E-05 x^{3.87}$

0.98

$0.34 x^{1.90}$

0.99

$0.27 x^{1.90}$

0.88

$4 E-05 x^{3.87}$

0.88

$0.16 x^{2.09}$

0.99

0.91

0.02

9.29

0.40

0.04

19.11

0.02

0.23

0.04

0.37

130.21

217.63

6.23

9.40

6.89

23.91

120.80

191.02

95.93

151.69

6.27

15.94

169.31

102.28

$0.0011 x^{2.88} \quad 0.99$

$0.0013 x^{2.88} \quad 0.99$

8.08

16.19

$0.0020 x^{2.51}$

0.86

9.55

19.13

$2 E-06 x^{2.88}$

0.99

4.68

8.58

0.03

$0.16 x^{2.18}$

0.93

0.01

6.29

0.55

6.92

0.61

0.08

34.15

0.08

0.53

329.10

7.48

50.70

276.24

219.37

33.80

254.05

4.12

4.69

8.25

2,631

0.28

0.35

4.28

4.88

1.06

212

2,748

236

24

9,742

$\begin{array}{lll}11.07 & 13.53 & 71.75\end{array}$

$\begin{array}{lll}0.02 & 0.05 & 0.21\end{array}$

0.26

0.30

0.85

$\begin{array}{lll}140.76 & 179.01 \quad 538.56\end{array}$

$\begin{array}{lll}6.20 & 6.80 & 8.10\end{array}$

$8.77 \quad 27.80 \quad 104.86$

131.99

105.59

151.22

433.70

346.96

5.53

17.51

66.06

$111.12 \quad 138.48 \quad 413.02$

28.32

7.69

17.18

48.47

55.74

22.32

13.97

8.84

19.76

4.77

3.67

0.10

25

187

108,161

12,558

95,602

76,482

7,912

84,394

8,343

9,595

4,404

20

Total above-ground woody biomass

Biomass of dry wood $(\mathrm{kg})$

Surface area of cambium $\left(\mathrm{m}^{2}\right)$

Biomass including bark $(\mathrm{kg})$

Outer surface area $\left(\mathrm{m}^{2}\right)$

Water content $(\mathrm{kg})$

Wood volume $\left(\mathrm{m}^{3}\right)$

Volume of wood and bark $\left(\mathrm{m}^{3}\right)$

$0.0151 x^{2.06}$

0.87

135.08

228.52

348.93

148.45

196.19

587.03

116,504

$0.14 x^{2.25}$

$0.92 \quad 146.75$

14.46

21.57

9.70

11.07

35.10

7,035

$0.0154 x^{2.06}$

0.87

46.75

252.48

390.80

159.52

209.72

658.78

126,246

$0.14 x^{2.16}$

0.93

111.11

22.00

9.87

11.25

35.67

7,152

$0.00030 x^{2.18} 0.93$

0.25

0.43

284.53

119.96

158.24

468.77

93,989

0.65

0.29

0.38

1.15

232

0.58

0.90

0.32

0.42

1.33

Roots

Volume of all roots $\left(\mathrm{m}^{3}\right)$

Volume of small and fine roots $\left(\mathrm{m}^{3}\right)$

Volume of coarse roots $\left(\mathrm{m}^{3}\right)$

Biomass of all roots $(\mathrm{kg})$

Surface area of all roots $\left(\mathrm{m}^{2}\right)$

Surface of small and fine roots $\left(\mathrm{m}^{2}\right)$

Surface area of coarse roots $\left(\mathrm{m}^{2}\right)$

Total woody biomass

Volume $\left(\mathrm{m}^{3}\right)$

Dry biomass $(\mathrm{kg})$

74,762

Surface area $\left(\mathrm{m}^{2}\right)$

The parameters of the stems and branches are calculated separately using the least square method. $x=\mathrm{DBH}, R^{2}=$ coefficient of determination. Volume, dry mass, corresponding surface area and water storage of different components of the above- and below-ground woody skeleton of generalized trees (i.e., each of the generalized trees is an average of one-third of the trees in the forest stand) and values of these quantities measured in three of sample trees. All those parameters are extrapolated to the stand level 
represented the projected (vertical, respectively horizontal) density of the skeleton parameters $\left(\rho_{\mathrm{cpv}}\right.$, respectively $\left.\rho_{\mathrm{cph}}\right)$. The cumulated values of the skeleton dry mass, the skeleton surface area and the water content of all clouds in different vertical layers (i) of $0.2 \mathrm{~m}$ in the canopy represented the vertical profile of the skeleton distribution, whereby the sum of all vertical layers represented the overall total of the individual tree.

$M_{L D . t}=\sum_{i=1}^{i=n} M_{L D . i}$

$A_{L . t}=\sum_{i=1}^{i=n} A_{L}$

Scaling-up total surface area, dry mass, volume and water content of the skeleton

The actual total area $\left(A_{\mathrm{L.t}}\right)$, the total dry mass $\left(M_{\mathrm{LD} . \mathrm{t}}\right)$, the total volume and the water content of the skeleton of the individual tree stem (separately for the sapwood, the heartwood and the bark) and of the branches were scaledup from the individual harvested sample trees to the trees of all diameter classes in the stand (with DBH intervals of $2 \mathrm{~cm}$ ). We used allometric relations (Table 1) between the above-mentioned parameters and the corresponding $\mathrm{DBH}$ of the harvested sample trees to calculate the area $\left(\mathrm{A}_{\mathrm{L} . \mathrm{tm}}\right)$ and the biomass $\left(\mathrm{M}_{\mathrm{LD} . \mathrm{tm}}\right)$ of the individual trees from $\mathrm{DBH}$.

$A_{\mathrm{L} . \mathrm{tm}}=f_{1}(D B H)$

$M_{L D . t m}=f_{2}(D B H)$

The total surface area $\left(A_{\mathrm{Ls}}\right)$, the total dry mass $\left(M_{\mathrm{LD} . \mathrm{s}}\right)$, the total volume of the skeleton and the total water content in the skeleton per unit of stand area ( $1 \mathrm{ha})$ were estimated by multiplying the values of the corresponding parameters for the average trees in the individual DBH classes with the number of trees in the respective classes and summarized as

$A_{\mathrm{L} . \mathrm{s}}=\sum_{m=1}^{m=n} A_{\mathrm{L} . \mathrm{tm}} * n_{\mathrm{m}}$

$M_{\text {LD.s }}=\sum_{m=1}^{m=n} M_{\text {LD.tm }} * n_{\mathrm{m}}$

Scaling-up of distribution of biomass, volume, surface area and water storage

The vertical distribution of the skeleton (volume, surface area, dry mass, water content) was scaled-up to the stand level using a two-steps approach (Čermák et al. 2008b). The distribution of the skeleton biomass and the surface area in different layers above the ground $\left(h_{\mathrm{i}}=\right.$ height in $m$ ) was approximated by a single equation for each sample tree, separately for the branches (total amount of branches, large branches and small branches) and for the stem. Canopy layers with a depth of $0.2 \mathrm{~m}$ (along the axis of the stem) were considered, so that the skeleton distribution $\left(y_{\mathrm{i}}\right)$ could be expressed in ( $\mathrm{kg}$ per $0.2 \mathrm{~m}$ layer) and/or in $\left(\mathrm{m}^{2}\right.$ per $0.2 \mathrm{~m}$ layer).

For the scaling-up of the branches, we used the double Gauss equations

$y=a \cdot \exp \left[-b\left(c-h_{i}\right)^{2}\right]+d \cdot \exp \left[-e\left(f-h_{i}\right)^{2}\right]-g ;$

For the scaling-up of the stem parameters, we used a three-parameter equation

$y=a \cdot \exp (b \cdot \exp (c \cdot \mathrm{DBH}))$

During the first step of the approximation, the parameters of the double Gauss Eq. (10) were calculated for branches $(a-g$, Table 2) and Eq. 11 for the stem (a-c, Table 3) for each of the sample trees. Coefficients were optimized by minimizing the residual sum of squares. These coefficients were plotted against the DBH and scaled-up by introducing an additional regression. Parameters of the main equation were derived for each DBH class from the above-mentioned additional equations. The spatial distribution of the skeleton in different horizontal layers was computed using the parameters derived via this approach. The total for the skeleton of an entire tree was calculated by summing the values of the skeleton distribution along the vertical stem axis. The values from individual trees in the DBH class were scaled-up to the entire stand by multiplying the value for the skeleton by the number of trees in the respective classes.

The amount and the spatial distribution of the parameters of the skeleton were calculated from the above-mentioned equations for the three generalized trees of a different social position (i.e., suppressed, co-dominant and dominant). The size of the generalized trees was calculated from the cumulated value of the tree basal areas in the diameter classes using the quantils of the total (Čermák and Michálek 1991). Each of the three generalized trees represented on average $33.3 \%$ of the tree asal area of the stand the experimental plot. The DBHs of the generalized trees were 22, 28 and 34 (for the suppressed, co-dominant and dominant tree, respectively).

Huber values

Huber values (HV; Huber 1928; Tyree and Ewers 1991) were calculated as the ratio of the cross-sectional area of the sapwood $\left(\mathrm{cm}^{2}\right)$ to the unit of needle dry biomass $(\mathrm{kg})$ supported by it. While sapwood area measurements are part of this contribution, the needle biomass (estimated for the 
Table 2 Regression parameters $(a-g)$ of Eq. 10 for three sample trees and coefficients of determination $\left(R^{2}\right)$ of the models

\begin{tabular}{llllllllll}
\hline & DBH $(\mathrm{cm})$ & $a$ & $b$ & $c$ & $d$ & $e$ & $f$ & $g$ & $R^{2}$ \\
\hline \multirow{2}{*}{ Dry weight } & 40.6 & 0.30 & 1.3 & 23.5 & 2.33 & 0.16 & 19.6 & 0.105 & 0.78 \\
& 28.5 & 0.74 & 0.8 & 20.3 & 0.80 & 0.28 & 19.0 & 0.105 & 0.51 \\
& 21.4 & 0.73 & 0.8 & 20.5 & 0.20 & 0.24 & 19.0 & 0.105 & 0.72 \\
Surface area & 40.6 & 0.28 & 1.3 & 23.5 & 1.31 & 0.15 & 19.8 & 0.105 & 0.81 \\
& 28.5 & 0.37 & 0.8 & 20.5 & 0.35 & 0.28 & 19.0 & 0.105 & 0.60 \\
\multirow{5}{*}{ Volume } & 21.4 & 0.39 & 0.6 & 20.6 & 0.25 & 0.30 & 19.5 & 0.105 & 0.67 \\
& 40.6 & 0.60 & 1.3 & 23.5 & 6.28 & 0.16 & 19.5 & 0.105 & 0.74 \\
& 28.5 & 2.12 & 0.9 & 20.3 & 1.20 & 0.28 & 18.8 & 0.105 & 0.58 \\
& 21.4 & 1.42 & 0.6 & 20.4 & 0.25 & 0.24 & 19.0 & 0.105 & 0.71 \\
\hline
\end{tabular}

$D B H$ diameter at breast height

Table 3 Regression parameters (a-c) of Eq. 11 for the estimation of tapering of the stem radius in the three sample trees and coefficients of determination $\left(R^{2}\right)$ of the models

same set of the trees) was taken up from the previous contribution (Čermák et al. 1998). The HV values were calculated at different levels in the tree: i.e., at breast height; below the living crown; as the sum of the sapwood areas at the base of the branches; at the onset of the green parts of the second-order axis; and at the base of the shoots. From the approach used in this contribution, the units of $\mathrm{HV}$ therefore were $\mathrm{cm}^{2} \mathrm{~kg}^{-1}$. Some authors (e.g., Mencuccini and Grace 1994; Mencuccini and Bonosi 2001; Sellin and Kupper 2006) prefer to express the Huber value as the needle area to the sapwood area ratio $\left(\mathrm{m}^{2} \mathrm{~cm}^{-2}\right)$. We therefore also calculated HV in this way.

\section{Statistical analysis}

All statistical analyses were performed using software STATISTICA 8.0 (StatSoft, Inc., Tulsa, USA). Allometric models were calculated using the methods of the linear and nonlinear least square regression analysis (Niklas 1994). We mainly used linear and power type functions and determined their corresponding $r^{2}$. Significance of the $r^{2}$ and of the model were tested by one-way ANOVA (analysis of variance, $\alpha=0.05)$. In case the calculated $F$ value was higher than the threshold value, we considered the proposed model as significant. In linear models, we also tested the significance of the absolute coefficient by a $t$ test for $t_{0.025, n-2}$. If the calculated value was lower than the threshold value, the coefficient was excluded from the equation. The model with the highest $r^{2}$ was selected for the up-scaling function. Significance of differences between two different groups was tested by t test. If there were more than two groups, we used a one-way ANOVA.

\section{Results}

Individual tree level

The stem volume of the mean tree was $0.44 \mathrm{~m}^{3}$ including the bark. The proportion of bark volume in the generalized

\begin{tabular}{lllll}
\hline $\mathrm{DBH}(\mathrm{cm})$ & $a$ & $b$ & $c$ & $R^{2}$ \\
\hline 40.6 & 17.5 & 2.1 & 0.2 & 0.96 \\
28.5 & 12 & 2.1 & 0.18 & 0.93 \\
21.4 & 9.7 & 2.1 & 0.175 & 0.92 \\
\hline
\end{tabular}

$\mathrm{DBH}$ diameter at breast height

trees (with a DBH of 22, 28 and 34 thus representing a suppressed, a mean and a dominant tree, respectively) was between 8 and $15 \%$ of the total stem volume; this value was higher in the larger trees (Table 1). The depth of the sapwood at breast height increased with tree size from 6.2 to $8.1 \mathrm{~cm}$ in the suppressed and the dominant tree, respectively. The corresponding surface area of the stem of the mean tree was $5.5 \mathrm{~m}^{2}$, and the stem surface area of the same tree without bark (area of above-ground woody cambium) was $5.1 \mathrm{~m}^{2}$ (Fig. 1). General allometric equations of the single tree biomass to $\mathrm{DBH}$ are listed in Table 1.

The top of a dominant tree (DBH of $34 \mathrm{~cm}$ ) was approximately $2 \mathrm{~m}$ higher than the top of the surrounding canopy and reached a height of $24.5 \mathrm{~m}$ (Fig. 2). The dominant tree had the longest (or deepest) crown of all studied trees (about $10 \mathrm{~m}$ ). The heights of co-dominant (DBH of $28 \mathrm{~cm}$ ) and suppressed (DBH of $22 \mathrm{~cm}$ ) trees were similar, about $22 \mathrm{~m}$. The vertical distribution of needle biomass (reported by Čermák et al. 1998 for the same set of harvested trees) followed those of the small branches (Fig. 2). We found a linear relationship between the size of the tree (DBH) and the total ratio of branch biomass to needle biomass (Fig. 3). This value increased with DBH from 1.2 to 1.9 in the suppressed and the dominant tree, respectively. On average, needle biomass made up for $40 \%$ of the total crown biomass (Fig. 3).

Huber values ranged from 29 to $38 \mathrm{~cm}^{-2} \mathrm{~kg}$ and were highest when calculated from the sapwood area at breast height (Table 4). The lowest values were typical for the 


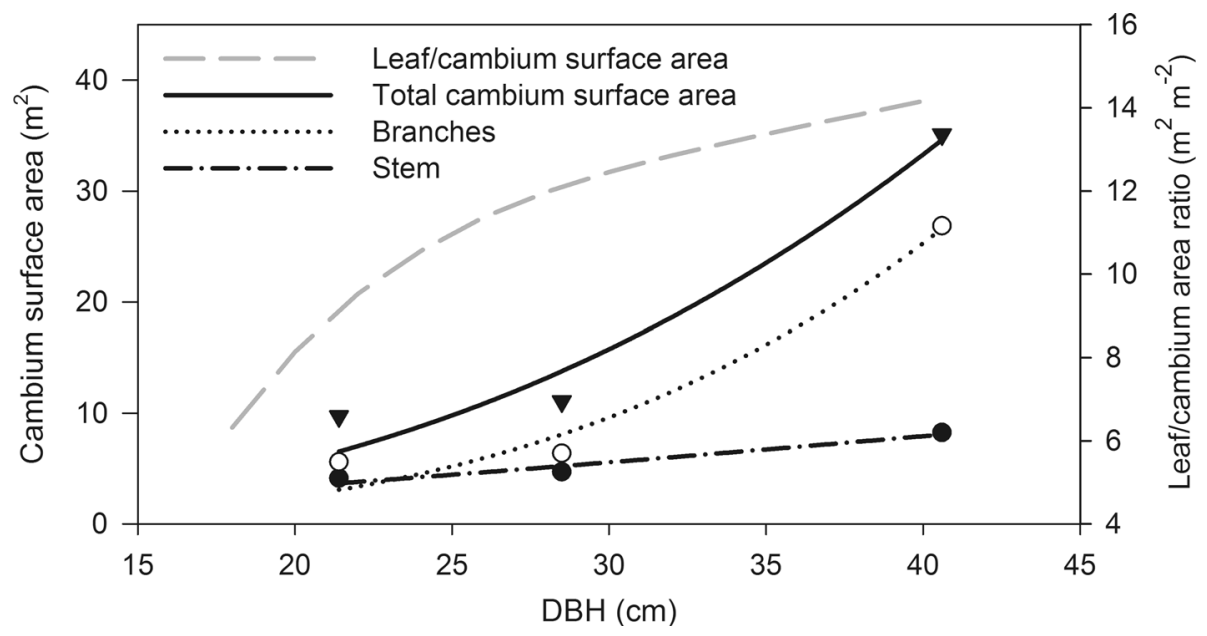

Fig. 1 Allometric relationship of above-ground woody cambium surface area to stem diameter at breast height (lines) and estimated surface areas of the sample trees (symbols). The proposed power models for total tree above-ground woody cambium surface area (full line, triangles), surface area of the stems (dot-dashed lines, full circles) and surface area of branches (dotted line, open circles). Graydashed line illustrates relation between the surface area of aboveground woody cambium and surface area of needles over the diameter classes

the canopy. Most of the xylem volume was found at the lowest $5 \mathrm{~m}$ of the stand, where between 2 and $2.5 \mathrm{dm}^{3}$ of wood per $\mathrm{m}^{3}$ of space was allocated. A second peak in vertical biomass distribution was found at a height of $20 \mathrm{~m}$ in the crown (or canopy) (Fig. 4a). At that height, also, most of the above-ground skeleton surface area was allocated $\left(0.13 \mathrm{~m}^{2} \mathrm{~m}^{-3}\right.$, Fig. $\left.4 \mathrm{~b}\right)$.

\section{Below-ground skeleton}

The woody root biomass accounted for $18 \%$ of the total woody mass of the tree. Earlier estimates were from $22.3 \mathrm{Mg} \mathrm{ha}^{-1}$ (Xiao et al. 2003) to $28.7 \mathrm{Mg} \mathrm{ha}^{-1}$ (Janssens et al. 1999). While most of the root volume was allocated in the coarse roots, most of the surface area was in the small and coarse roots (Table 1). There was a considerable difference between the total root surface areas in the winter $(\mathrm{RAI}=3.75)$ and in the spring $(\mathrm{RAI}=6.76)$. The values between winter and spring varied by $45 \%$ mostly because of the different amount of finest roots (diameter $<1 \mathrm{~mm}$ ), i.e., RAI 5.10 and 2.40 in spring and winter, respectively. The largest fraction of the root surface was, similarly to the root biomass, located in the top $20 \mathrm{~cm}$ of the soil (Fig. 5). During the growing season, the RAI was two times higher than the surface area of the needles and almost ten times higher than the total surface area of the above-ground skeleton.

\section{Water in the xylem}

Density of the dry xylem biomass was different in the stem and in the branches, respectively, reaching $510 \pm 12$ and 


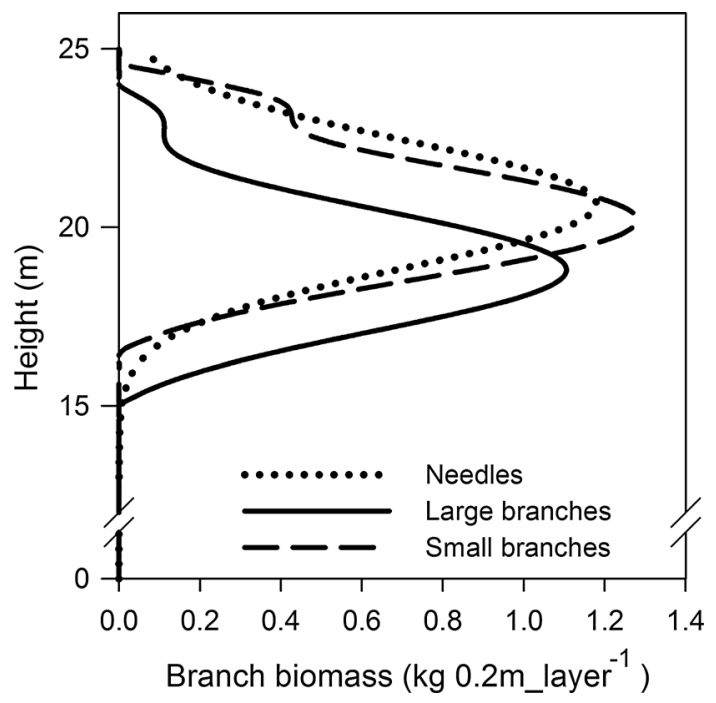

Fig. 2 Vertical distribution of the needles and branches in a dominant Scots pine tree. Full line: large branches (diameter $\geq 2.5 \mathrm{~cm}$ ); dashed line: small branches (diameter $0-2.5 \mathrm{~cm}$ ); dotted line: needles. The double Gaussian equation was used to smoothen the data. Needle biomass data are derived from Čermák et al. (1998)

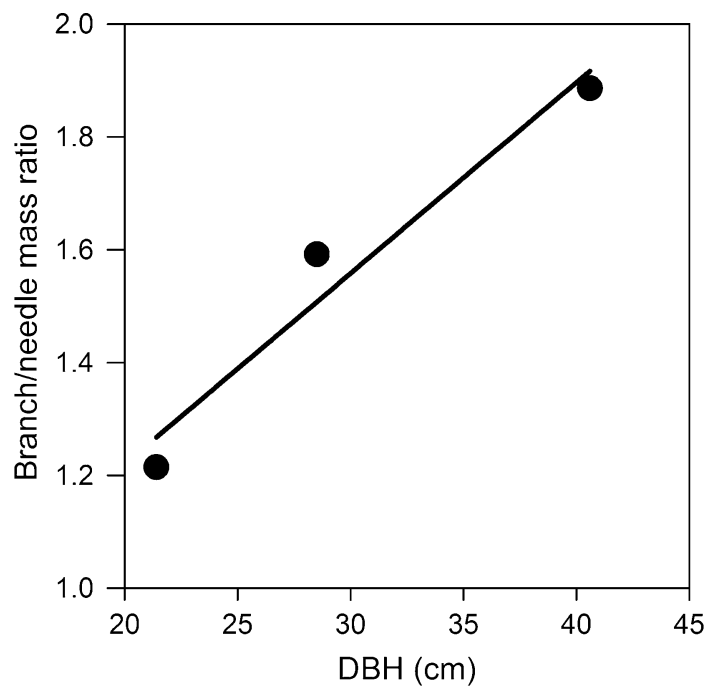

Fig. 3 Ratio of branch dry mass to needle dry mass in trees of various sizes. $\mathrm{DBH}=$ diameter at breast height. Regression equation is $y=0.54+0.034 * \mathrm{DBH}\left(n=3, R^{2}=0.95\right)$

$410 \pm 25 \mathrm{~kg} \mathrm{~m}^{-3}$ ( \pm standard deviation, SD). We did not observe any significant difference in xylem density between individual trees of different size, or between the sapwood and the heartwood. The mean water content was 321,408 and $472 \mathrm{~kg} \mathrm{~m}^{-3}$ in the heartwood, the sapwood and the branches, respectively. For RWC, the values were $63 \pm 3 \%, 80 \pm 1 \%$ and $115 \pm 13 \%( \pm \mathrm{SD})$ for the heartwood, the sapwood and the branches. Water storage in the above-ground woody skeleton (stem + branches) of the generalized trees was 110,180 and $280 \mathrm{dm}^{3}$ in the small, the medium and the dominant tree, respectively. The
Table 4 Huber values $\left(\mathrm{cm}^{2} \mathrm{~kg}^{-1}\right)$ of Scots pine trees of three different social categories

\begin{tabular}{lcrc}
\hline & Dominant & Mean & Suppressed \\
\hline Breast height & 29.0 & 33.3 & 37.7 \\
Under crown & 11.8 & 7.2 & 13.5 \\
Branches at stem & 18.9 & 22.2 & 11.3 \\
Branches at green & 10.8 & 13.5 & 7.7 \\
Shoots & 3.2 & 5.1 & 10.9 \\
\hline
\end{tabular}

The Huber value was calculated as the cross-sectional area of the sapwood $\left(\mathrm{cm}^{2}\right)$ to the amount of needle biomass $(\mathrm{kg})$ supported by it at different horizontal levels in the canopy

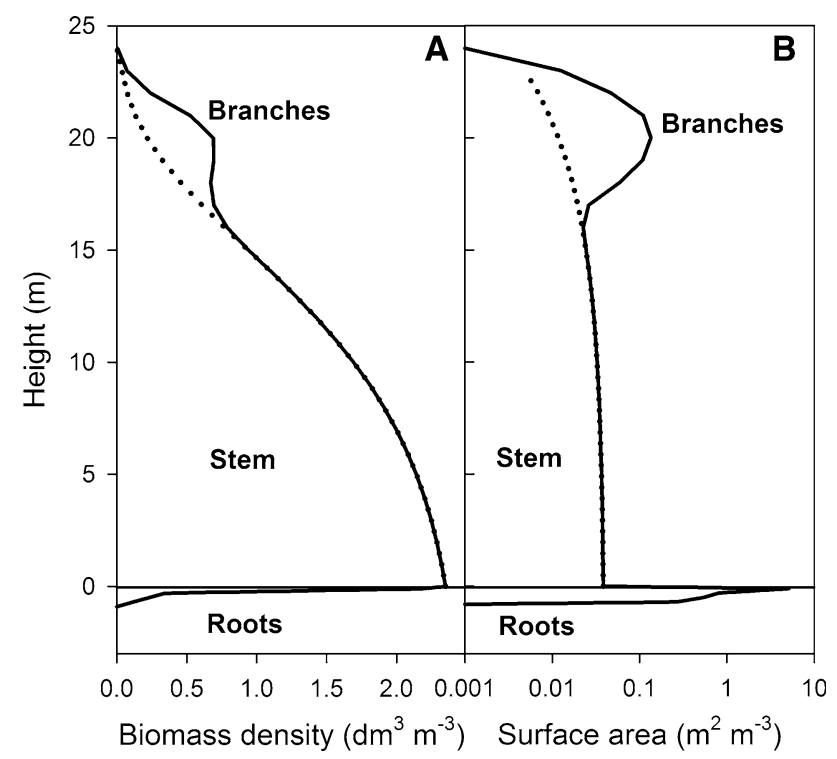

Fig. 4 Generalized vertical distribution of volume (left panel, $A$ ) and surface area (right panel, $B$ ) of the stem and the branches at the stand level. Full outer line: cumulative distribution of the stem and branches; dashed inner line: only stem

total water storage in the above-ground woody tissues was $94 \mathrm{Mg} \mathrm{ha}^{-1}$ (or $9.4 \mathrm{~mm}$ ). Most of this water was contained in the sapwood of the stems $(7.6 \mathrm{~mm}$, Table 1$)$. From this $9.4 \mathrm{~mm}$ of the stored water, $2 \mathrm{~mm}$ were available for transpiration at the time of sampling (Fig. 6).

\section{Discussion}

Individual tree level

Our results on the distribution of the branches in the crown confirmed earlier studies (Kellomäki et al. 1980; Baldwin et al. 2000; Mäkëla and Vanninen 2001) indicating that the vertical maximum of the needle and branch biomass of the dominant trees was lower than in the suppressed trees. The ratios of the needle to the branch biomass and the needle to the branch surface areas provide an insight in the assimilation and 
Fig. 5 Vertical distribution of biomass $(A$, left panel $)$ and surface area $(B$, right panel $)$ of the roots in the soil for different root diameter classes and for 0.2-m-thick soil depth layers. The total root biomass $\left(\mathrm{M}_{\text {root }}\right.$, $\mathrm{Mg} \mathrm{ha}^{-1}$ ) per 20-cm-thick layer at a given mean depth $\left(\mathrm{H}_{\text {soil }}\right)$ is $M_{\text {root }}=-13.04+13.14 * H_{\text {soil }} /$ $\left(6.23+H_{\text {soil }}\right),(n=4$,

$\left.R^{2}=0.99\right)$ and the total root surface area $\left(\mathrm{A}_{\text {root }}, \mathrm{m}^{2} \mathrm{ha}^{-1}\right)$ : $A_{\text {root }}=-30729+$ $30957 * H_{\text {soil }} /\left(6.23+H_{\text {soil }}\right)$, $\left(n=4, R^{2}=0.99\right)$

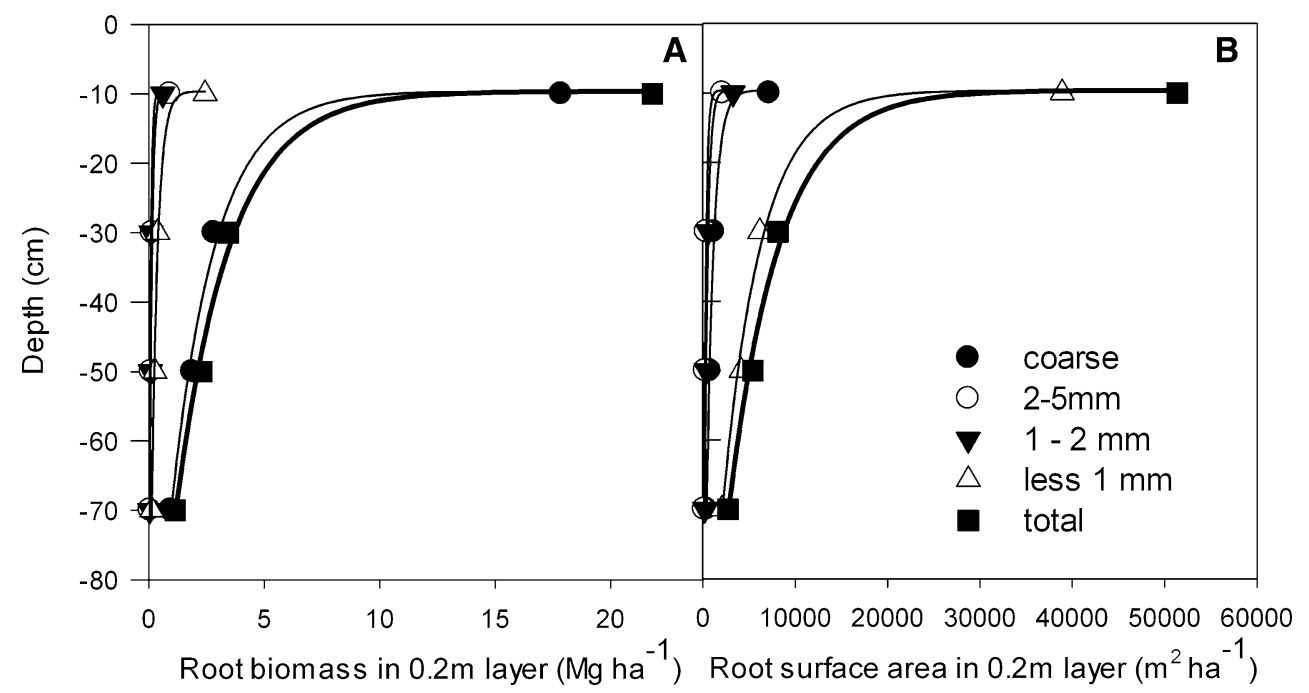

respiration patterns of the tree. In the case of our forest site, branches contribute for the largest part to the above-ground tree cambium surface area. The above-ground woody skeleton cambium area to needle surface area ratio, which is more favorable in larger trees (Fig. 1), therefore serve as a relative measure of the economy in the investment of assimilates. The ratio of the needle biomass to the total crown biomass (40\%) was comparable to the fraction of $34 \%$ reported by Monserud et al. (1996) for Scots pine in Russia.

The HV is an indicator of the long-time hydraulic adjustment to local climatic conditions, also in Scots pine (e.g., Berninger et al. 1995; Poyatos et al. 2007; MartínezVilalta et al. 2009). Our observations on HV at breast height were in line with the values reported for Scots pine from a range of various sites (Mencuccini and Bonosi 2001; Poyatos et al. 2007) and were closer to drier sites (Martínez-Vilalta et al. 2009). The HV values for the base of the crown and for branches were slightly higher than HV reported by Mencuccini and Grace (1994) and Mencuccini and Bonosi (2001). In trees of a different social status, the $\mathrm{HV}$ is a measure of their investment into the conductive pathways per unit of the leaf area fed by these pathways (Tyree and Ewers 1991). The largest sapwood area per leaf area was found in the smallest trees (Table 4). This feature protects suppressed trees against xylem cavitation because the cavitation risk in their xylem is increased by maintaining lower water potentials (Sellin 2001) and by lower xylem hydraulic conductivity (Reid et al. 2003).

Stand level

\section{Above-ground skeleton}

The total stem volume and the fraction of the branches were similar to the values reported for Scots pine stands in the temperate zone (Vogt 1991). The vertical distribution

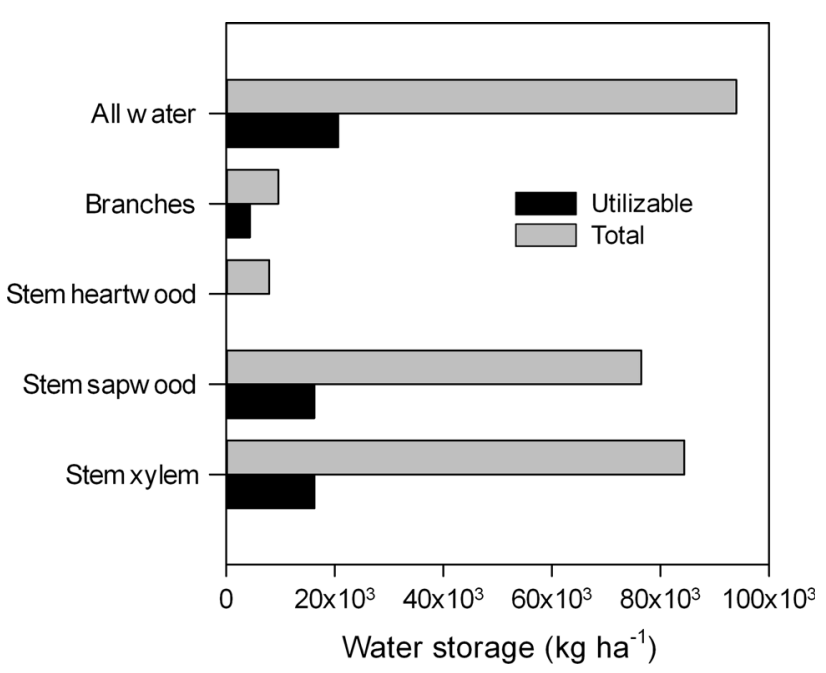

Fig. 6 Analysis of the available and stored water in a forest stand. Total and accessible water storage in the different tree compartments: the xylem of the stem, the sapwood of the stem, the heartwood of the stem, the branches and the total for the entire woody tree skeleton

of the stem biomass reflected stem taper (Fig. 4, Garber and Maguire 2003; Younger et al. 2008). The proportion of branch biomass from total above-ground woody mass (7\%) was similar to the values at old stands on fertile sites (Vanninen et al. 1996) but lower than $11 \%$ in a stand of similar age in Eastern Finland (Helmisaari et al. 2002). However, the mean DBH, height and stocking volume of the above-mentioned stand in Finland were lower, as a result of less favorable growing conditions, which inevitably resulted in a higher allocation of biomass into the branches (Poorter et al. 2012).

The above-ground woody cambium surface area $\left(7,035 \mathrm{~m}^{2} \mathrm{ha}^{-1}\right)$ was very close to the $6,500 \mathrm{~m}^{2} \mathrm{ha}^{-1}$ (Korf 1974) for Scots pine. The surface areas of the cambium of these two Scots pine stands (in Belgium and in the 
Czech Republic) were very similar, despite the significantly smaller tree size in the study of Korf (1974). The comparable CAI in these two forests supports the hypothesis that the cambium surface area of a forest stand increases until the age of 40-50 years and then remains approximately constant (Anučin 1959). As in our study, Korf (1974) estimated cambium area on harvested trees from mean diameter and length of a section (Eq. 3). Above-ground CAI is usually very close to the woody area index (WAI), (defined, i.e., in Bréda 2003) which can be estimated by the optical-based methods. However, different methods of measurements as well as variation in tree age, site quality and stand density may impose large source of variation within a specific species (Smolander and Stenberg 1996; Weiskittel and Maguire 2006). WAI of our forest site comprised $19 \%$ from the above-ground plant area index (PAI), which fells into the range 3-33\% listed by Bréda (2003) for various pine species. But it is almost twice as much as $10 \%$ estimated by hemispherical photography (Walter and Grégoire-Himmler 1996) and still more than $14 \%$ from direct measurements in a 25-year-old (i.e., three times younger) Scots pine stand (Smolander and Stenberg 1996).

\section{Below-ground skeleton}

The fraction of root biomass from the total $(18 \%)$ was identical to the value reported for a 36-year-old boreal forest (Ilvesniemi and Liu 2001) and similar to the $13 \%$ in a 100-year-old Scots pine stand in Eastern Finland (Helmisaari et al. 2002). It was also within the range of 5-40 \% reported in the literature for various coniferous forests (i.e., Jackson et al. 1996; Thies and Cunningham 1996; Drexhage and Gruber 1999; Do-Hyung 2001). Most of the below-ground biomass (76\%) was located in the top $20 \mathrm{~cm}$ of the soil and in the coarse roots with a diameter larger than $5 \mathrm{~mm}$ (Fig. 5a). The amount of the roots decreased with depth. Various authors described a similar root distribution (e.g., Roberts 1975; Persson 1983; Nadezhdina et al. 2007; Čermák et al. 2008a; Børja et al. 2008). This type of vertical distribution of coarse roots emphasizes the high importance of precipitation compared to the groundwater (Tatarinov et al. 2008). The seasonal variation of the root surface area reflected the different demand for the absorption of water and nutrients. A twofold change in the surface area between the spring and the winter (Janssens et al. 1999; Xiao et al. 2003) was linked with the changes in the surface area of small and fine roots and was in line with the observed variability in a Scots pine forest stand in Sweden (Persson 1978).

The RAI observed in this study was close to the RAI values of 6.8 for a European beech and 5.4 for a Norway spruce stand (van Praag et al. 1988). Higher values of RAI than LAI were often reported for different forest ecosystems (Jackson et al. 1996), for Scots pine forests (Ilvesniemi and Liu 2001; Addington et al. 2006) and for a Norway spruce stand (Do-Hyung 2001). But in some cases, i.e., in a short-rotation poplar coppice, values of RAI $\left(1.7-3.7 \mathrm{~m}^{2}\right.$ $\mathrm{m}^{-2}$ ) could be much lower than those of LAI (2.1-6) (Al Afas et al. 2008).

\section{Water in the xylem}

The water content in the xylem is a dynamic value that changes on a diurnal as well as on a seasonal basis. Upon rapidly changing weather conditions and low availability of the soil water, as much as half of the transpired water can be extracted from the water stored in the sapwood over short periods (Waring et al. 1979; Phillips et al. 2003; Čermák et al. 2007; Hernández-Santana et al. 2008). Therefore, our results provide only a one-time estimate of the water storage in the Scots pine stand. Our data of water storage in the sapwood corresponded well with the measured water storage of 6.4 to $7.5 \mathrm{~mm}$ in the stem sapwood of 50- and 100-yearold Scots pine stands on a sandy soil in central Sweden (Kravka et al. 1999). Similarly, the mean water content in the sapwood of $400 \mathrm{~kg} \mathrm{~m}^{-3}$ (Kravka et al. 1999) was very close to the $408 \mathrm{~kg} \mathrm{~m}^{-3}$ in the present study. On the contrary, the xylem water content of $120 \mathrm{~kg} \mathrm{~m}^{-3}$ in the heartwood measured by Kravka et al. (1999) in central Sweden was two times lower than here. The water content in the heartwood does not change much over the season; this reflects the hydraulic separation between the living portions of the stem and of the heartwood (Holbrook, 1995). Therefore, high moisture in the heartwood may have been induced by constantly high water availability at our research site (Ehleringer and Dawson 1992; Kumagai et al. 2009).

\section{Ecophysiological significance of relations among various biometric parameters}

On average, $7 \mathrm{~m}^{2}$ of needles colonized each unit of surface area at branches. The photosynthetically active organsneedles-feed the "heterotrophic" parts of the tree, primarily the living cells of the cambium layers. On average, one unit of surface area of needles fed $0.25 \mathrm{~m}^{2}$ of the aboveground cambium and $1-2 \mathrm{~m}^{2}$ of the total cambium surface area. The amount of needles supporting the unit of the tree cambium area (Table 4, Fig. 1) was smaller in smaller trees. This ratio may be an indicator of the lower growth increment potential of the suppressed trees, but also, on the one hand, of their better hydraulic safety margins (Choat et al. 2012). The LAI (reaching a value of 3 ) was comparable to the RAI (3-7), emphasizing the mutual physiological roles of those two active surfaces (i.e., the transpiratory surface area vs. the water absorptive surface area). 


\section{Conclusions}

In this contribution, we provided allometric equations on biomass and surface areas of above- and below-ground tree organs in a mature Scots pine stand. These equations are necessary background information for up-scaling of physiological data measured on the spatially limited level (i.e., respiration of various tree organs). Similarly, process-based models operate on a unit area level and the operator needs to know the stand biometry to either downscale empirically measured input data or to upscale the model outputs. Total woody biomass of the 66-year-old forest stand was $155 \mathrm{Mg} \mathrm{ha}^{-1}$, i.e., $126 \mathrm{Mg} \mathrm{ha}^{-1}$ above ground and $29 \mathrm{Mg} \mathrm{ha}^{-1}$ below ground. These values can be linked to the carbon storage. The amount of stored water in this biomass available for transpiration $\left(2 \mathrm{dm}^{3} \mathrm{~m}^{-2}\right)$ plays a role in mitigating the effect of drought stress on a tree. Speaking about stress, the surface area of needles supported by unit of cross-sectional area of sapwood provides information about individual tree resistance. Total surface area of the woody skeleton was 75,000 $\mathrm{m}^{2} \mathrm{ha}^{-1}$. Most of the surface area of the skeleton (90\%) was in the roots. This could be linked to the number of living cells and sheds light on the partitioning of the above-ground and below-ground tree respiration. The relation between the above-ground woody surface area and the needle surface area defines the fraction of intercepted radiation available for photosynthesis. A comparative analysis of the biometric parameters showed the balance between the different functionally connected, operational surface areas of the trees in the stand (i.e., root to needle surface areas).

Acknowledgments We thank I.A. Janssens, D. de Pury, V. Gond and N. Calluy for their valuable help with field and laboratory measurements. We are also grateful to J. Van Slycken(+) and S. Overloop (INBO, Geraardsbergen) for their logistic support at the forest site. This research was financially supported by the Sixth Framework Programme of the European Commission as Carbo-Europe IP (contract no. GOCECT-2003-505572), by the Flemish-Czech Bilateral Scientific Cooperation project (UA-BOF-1-2006-19), by the COST MŠMT LD13017 and by the Investments in Education Development (contract no. OPVK CZ.1.07/2.3.00/30.0017) co-financed by the European Social Fund and the state budget of the Czech Republic. This work was part of the Global Change and Terrestrial Ecosystems Core project of the International Geosphere-Biosphere Programme (IGBP).

Conflict of interest The authors declare that they have no conflict of interest.

Open Access This article is distributed under the terms of the Creative Commons Attribution License which permits any use, distribution, and reproduction in any medium, provided the original author(s) and the source are credited.

\section{References}

Acosta M, Pavelka M, Pokorny R, Janous D, Marek MV (2008) Seasonal variation in $\mathrm{CO}_{2}$ efflux of stems and branches of Norway spruce trees. Ann Bot 101:469-477
Addington RN, Donovan LA, Mitchell RJ, Vose JM, Pecot SD, Jack SB, Hacke UG, Sperry JS, Oren R (2006) Adjustments in hydraulic architecture of Pinus palustris maintain similar stomatal conductance in xeric and mesic habitats. Plant, Cell Environ 29:535-545

Al Afas N, Marron N, Zavaloni C, Ceulemans R (2008) Growth and production of a short-rotation coppice culture of poplar-IV: fine root characteristics of five poplar clones. Biomass Bioenergy 32:494-502

Anučin NP (1959) Novyj metod opredelenija tekuščego pritosta nasaždenij. Lesnoje Chozjajstvo 11:40-42 (in Russian)

Baeyens L, Van Slycken J, Stevens D (1993) Description of the soil profile in Brasschaat. Internal research paper, Institute of Forestry and Game Management, Geraardsbergen, Belgium

Baldwin VC, Peterson KD, Clark A, Ferguson RB, Strub M, Bower DR (2000) The effect of spacing and thinning on stand and tree characteristics of 38-year-old Loblolly pine. For Ecol Manag 137:97-102

Bartelink HH (1997) Allometric relationship for biomass and leaf area of beech (Fagus sylvatica, L.). Ann For Sci 54:39-50

Berninger F, Nikinmaa E, Hari P, Mencuccini M, Grace J (1995) Evaporative demand determines branchiness of scots pine. Oecologia 102:164-168

Børja I, de Wit HA, Steffenrem D, Majdi H (2008) Stand age and fine root biomass, distribution and morphology in a Norway spruce chronosequence in southeast Norway. Tree Physiol 28:773-784

Bréda NJJ (2003) Ground-based measurements of leaf area index: a review of methods, instruments and current controversies. J Exp Bot 54:2403-2417

Cannell MGR (1982) World forest biomass and primary production data. Academic Press, London

Carrara A, Kowalski AS, Neirynck J, Janssens IA, Curiel Yuste J, Ceulemans R (2003) Net ecosystem $\mathrm{CO}_{2}$ exchange of mixed forest in Belgium over 5 years. Agric For Meteorol 119:209-227

Čermák J, Kučera J (1990) Scaling up transpiration data between trees, stands and watershed. Silva Carelica 15:101-120

Čermák J, Michalek J (1991) Selection of sample trees in forest stands using the quantils of total (in Czech). Lesnictvi 37:49-60

Čermák J, Úlehla J, Kučera J, Penka M (1982) Sap flow rate and transpiration dynamics in the full-grown oak (Quercus robur L.) in floodplain forest exposed to seasonal floods as related to potential evapotranspiration and tree dimensions. Biol Plant 24:446-460

Čermák J, Riguzzi F, Ceulemans R (1998) Scaling up from the individual tree to the stand level in Scots pine. I. Needle distribution, overall crown and root geometry. Ann For Sci 55:63-88

Čermák J, Kučera J, Bauerle WL, Phillips N, Hinckley TM (2007) Tree water storage and its diurnal dynamics related to sap flow and changes in stem volume in old-growth Douglas-fir trees. Tree Physiol 27:181-198

Čermák J, Nadezhdina N, Meiresonne L, Ceulemans R (2008a) Scots pine root distribution derived from radial sap flow patterns in stems of large leaning trees. Plant Soil 305:61-75

Čermák J, Tognetti R, Nadezhdina N, Raschi A (2008b) Stand structure and foliage distribution in Quercus pubescens and Quercus cerris forests in Tuscany (central Italy). For Ecol Manag 255:1810-1819

Čermák J (1990) Field measurement of vertical and radial leaf distribution in large broadleaf trees by the "cloud technique". In: Manual of eco-physiological methods. Mendel University of Agriculture and Forestry, Brno, Czech Republic, pp 1-10

Choat B, Jansen S, Brodribb TJ, Cochard H, Delzon S, Bhaskar R, Bucci SJ, Field TS, Gleason SM, Hacke UG, Jacobsen AL, Lens F, Maherali H, Martínez-Vilalta J, Mayr S, Mencuccini M, Mitchell PJ, Nardini A, Pittermann J, Pratt RB, Sperry JS, 
Westoby M, Wright IJ, Zanne AE (2012) Global convergence in the vulnerability of forests to drought. Nature 491:752-755

Claesson S, Sahlén K, Lundmark T (2001) Functions for biomass estimation of young Pinus sylvestris, Picea abies and Betula spp. from stands in northern Sweden with high stand densities. Scand J For Res 16:138-146

Cochard H (2006) Cavitation in trees. Comptes Rendus de Phys 7:1018-1026

Damesin C, Ceschia E, Le Goff N, Ottorini J-M, Dufrêne E (2002) Stem and branch respiration of beech: from tree measurements to estimations at the stand level. New Phytol 153:159-172

Do-Hyung L (2001) Relationship between above- and below-ground biomass for Norway spruce (Picea abies): estimating root system biomass from breast height diameter. J Korean For Soc 90:338-345

Drexhage M, Gruber F (1999) Above and below-stump relationships for Picea abies: estimating root system biomass from breastheight diameters. Scand J For Res 14:328-333

Edwards NT, Hanson PJ (1996) Stem respiration in a close-canopy upland oak forest. Tree Physiol 16:433-439

Ehleringer J, Dawson T (1992) Water uptake by plants: perspectives from stable isotope composition. Plant, Cell Environ 15: 1073-1082

Garber SM, Maguire DA (2003) Modeling stem taper of three central Oregon species using nonlinear mixed effects models and autoregressive error structures. For Ecol Manag 179:507-522

Gartner BL, Meinzer FC (2005) Structure-function relationships in sapwood water transport and storage. In: Holbrook M, Zwieniecki MA (eds) Vascular transport in plants. Academic Press, Cambridge, pp 307-331

Goldstein G, Andrade JL, Meinzer FC, Holbrook NM, Cavelier J, Jackson P, Celis A (1998) Stem water storage and diurnal patterns of water use in tropical forest canopy trees. Plant, Cell Environ 21:397-406

Helmisaari HS, Makkonen K, Kellomäki S, Valtonen E, Mälkönen E (2002) Below- and above-ground biomass, production and nitrogen use in Scots pine stands in eastern Finland. For Ecol Manag 165:317-326

Hernández-Santana V, David TS, Martínez-Fernández J (2008) Environmental and plant-based controls of water use in a Mediterranean oak stand. For Ecol Manag 255:3707-3715

Holbrook NM (1995) Stem water storage. In: Gartner B (ed) Plant stems: physiology and functional morphology. Academic Press, London, pp 151-174

Honzová M, Cermák J (2011) Calculation of the size of the surface area of deciduous trees and their potential for eventual use in a forensic-expert practice. ExFoS-Expert forensic science, XXI. International Scientific Conference on Forensic Engineering. 20-21.01.2012, pp 1-11

Huber B (1928) Weitere quantitative Untersuchungen uber das Wasserieitungssystem der Pflanzen. Jahrbiicher fiir Wissenschaftiiche Botanik 67:877-959

Ilvesniemi H, Liu Ch (2001) Biomass distribution in a young Scots pine stand. Boreal Environ Res 6:3-8

Jackson RB, Canadell J, Ehleringer JR, Mooney HA, Sala OE, Schulze ED (1996) A global analysis of root distribution for terrestrial biomes. Oecologia 108:389-411

Janssens IA, Sampson DA, Čermák J, Meiresonne L, Riguzzi F, Overloop S, Ceulemans R (1999) Above-and belowground phytomass and carbon storage in a Belgian Scots pine stand. Ann For Sci 56:81-90

Kellomäki S, Hari P, Kanninen M, Ilonen P (1980) Eco-physiological studies on young Scots pine stands. II. Distribution of needle biomass and its application in approximating light conditions in the canopy. Silva Fenn 14:243-257
Kim MH, Nakane K, Lee JT, Bang HS, Na YE (2007) Stem/branch maintenance respiration of Japanese red pine stand. For Ecol Manag 243:283-290

Konopka B, Noguchi K, Sakata T, Takahashi M, Konopkova Z (2006) Fine root dynamics in a Japanese cedar (Cryptomeria japonica) plantation throughout the growing season. For Ecol Manag 225:278-286

Konôpka B, Yuste JC, Janssens IA, Ceulemans R (2005) Comparison of fine root dynamics in Scots pine and Pedunculate oak in sandy soil. Plant Soil 276:33-45

Konôpka B, Pajtík J, Moravčík M, Lukac M (2010) Biomass partitioning and growth efficiency in four naturally regenerated forest tree species. Basic Appl Ecol 11:234-243

Köppen W (1936) Das geographische system der Klimate. In: Handbuch der Klimatologie. Köppen W, Geiger G (eds), Gebr., Borntraeger, pp 1-44

Korf V (1974) The surface area of cambium of a forest trees and its relation to taxation parameters (in Czech). Vysoka skola zemedelska Praha p 77

Kravka M, Krejzar T, Cermák J (1999) Water content in stem wood of large pine and spruce trees in natural forests in central Sweden. Agric For Meteorol 98-99:555-562

Kumagai T, Aoki S, Otsuki K, Utsumi Y (2009) Impact of stem water storage on diurnal estimates of whole-tree transpiration and canopy conductance from sap flow measurements in Japanese cedar and Japanese cypress trees. Hydrol Process 23:2335-2344

Landsberg J, Mäkelä A, Sivanen R, Kukkola M (2005) Analysis of biomass accumulation and stem size distribution over long periods in managed stands of Pinus sylvestris in Finland using the 3-PG model. Tree Physiol 25:781-792

Maherali H, de Lucia EH (2000) Xylem conductivity and vulnerability to cavitation of ponderosa pine growing in contrasting climates. Tree Physiol 20:859-867

Mäkelä A, Vanninen P (2001) Vertical structure of Scots pine crowns in different age and size classes. Trees 15:385-392

Martínez-Vilalta J, Cochard H, Mencuccini M, Sterck F, Herrero A, Korhonen JFJ, Llorens P, Nikinmaa E, Nolè A, Poyatos R, Ripullone F, Sass-Klaassen U, Zweifel R (2009) Hydraulic adjustment of Scots pine across Europe. New Phytol 184:353-364

Mencuccini M, Bonosi L (2001) Leaf/sapwood area ratios in Scots pine show acclimation across Europe. Can J For Res 31:442-456

Mencuccini M, Grace J (1994) Climate influences the leaf area/ sapwood area ratio in Scots pine. Tree Physiol 15:1-10

Monserud RA, Onuchin AA, Tchebakova NM (1996) Needle, crown, stem and root phytomass of Pinus sylvestris stands in Russia. For Ecol Manag 82:59-67

Nadezhdina N, Tatarinov F, Ceulemans R (2004) Leaf area and biomass of Rhododendron understorey in a stand of Scots pine. For Ecol Manag 187:235-246

Nadezhdina N, Čermák J, Meiresonne L, Ceulemans R (2007) Transpiration of Scots pine in Flanders growing on soil with irregular substratum. For Ecol Manag 243:1-9

Niklas KJ (1994) Plant allometry. The scaling of form and process. The University of Chicago Press, Chicago, p 395

Ogasa M, Miki NH, Murakami Y, Yoshikawa K (2013) Recovery performance in xylem hydraulic conductivity is correlated with cavitation resistance for temperate deciduous tree species. Tree Physiol 33:335-344

Persson H (1978) Root dynamics in a young Scots pine stand in central Sweden. Oikos 30:508-519

Persson HA (1983) The distribution and productivity of fine roots in boreal forests. Plant Soil 71:77-101

Peters J, González-Rodríguez AM, Jiménez MS, Morales D, Wieser G (2008) Influence of canopy position, needle age and season on 
the foliar gas exchange of Pinus canariensis. Eur J For Res 127:293-299

Phillips NG, Ryan MG, Bond BJ, McDowell NG, Hinckley TM, Čermák J (2003) Reliance on stored water increases with tree size in three species in the Pacific Northwest. Tree Physiol 23:237-245

Poorter H, Niklas KJ, Reich PB, Oleksyn J, Poot P, Mommer L (2012) Biomass allocation to leaves, stems and roots: meta-analyses of interspecific variation and environmental control. New Phytol 193:30-50

Poyatos R, Martinez-Vilalta J, Čermák J, Ceulemans R, Granier A, Irvine J, Kostner B, Lagergren F, Meiresonne L, Nadezhdina N, Zimmermann R, Llorens P, Mencuccini M (2007) Plasticity in hydraulic architecture of Scots pine across Eurasia. Oecologia 153:245-259

Reid DEB, Silins U, Lieffers VJ (2003) Stem sapwood permeability in relation to crown dominance and site quality in self-thinning fire-origin lodgepole pine stands. Tree Physiol 23:833-840

Richardson DM (1998) Ecology and biogeography of Pinus. Cambridge University Press, Cambridge

Roberts J (1975) A study of root distribution and growth in a Pinus sylvestris L. (Scots pine) plantation in East Anglia. Plant Soil 44:607-621

Sala A, Tenhunen JD (1996) Simulations of canopy net photosynthesis and transpiration in Quercus ilex L. under the influence of seasonal drought. Agric For Meteorol 78:203-222

Schlesinger WG (1997) Biogeochemistry: an analysis of global change, 2nd edition. Academic Press, New York

Sellin A (2001) Hydraulic and stomatal adjustment of Norway spruce trees to environmental stress. Tree Physiol 21:879-888

Sellin A, Kupper P (2006) Spatial variation in sapwood area to leaf area ratio and specific lea area within a crown of silver birch. Trees 20:311-319

Shinozaki KK, Yoda K, Hozumi L, Kira T (1964) A quantitative analysis of plant form-the pipe model theory. I. Basic Anal Jpn J Ecol 14:97-105

Smolander H, Stenberg P (1996) Response of LAI-2000 estimates to changes in plant surface area index in a Scots pine stand. Tree Physiol 16:345-350

Stanners D, Bourdeau P (1995) Europe's environment-the Dobris assessment. European Environment Agency, Copenhagen

Stoll P, Schmid B (1998) Plant foraging and dynamic competition between branches of Pinus sylvestris in contrasting light environments. J Ecol 86:934-945

Tack G, van den Bremt P, Hermy M (1993) Bossen van Vlaanderen: een historische ecologie. Davidsfonds, Leuven, Belgium (in Dutch)

Tatarinov F, Urban J, Čermák J (2008) Application of "clump technique" for root system studies of Quercus robur and Fraxinus excelsior. For Ecol Manag 255:495-505
Thies WG, Cunningham PG (1996) Estimating large-root biomass from stump and breast-height diameters for Douglas-fir in Western Oregon. Can J For Res 26:237-243

Tyree MT, Ewers FW (1991) The hydraulic architecture of trees and other woody plants. New Phytol 119:345-360

Urban J, Tatarinov F, Nadezhdina N, Čermák J, Ceulemans R (2009) Crown structure and leaf area of the understorey species Prunus serotina. Trees Struct Funct 23: 391-399

Urban J, Holušová K, Menšík L, Čermák J, Kantor P (2013) Tree allometry of Douglas fir and Norway spruce on a nutrient-poor and a nutrient-rich site. Trees Struct Funct 27:97-110

Van den Berge K, Maddelein D, De Vos B, Roskams P (1992) Analysis of the air pollution and its consequences for the forest ecosystem. Study report no. 19 of AMINAL, Ministry of the Flemish Community (in Dutch)

Van Praag HJ, Sougnez-Remy S, Weissen F, Carletti G (1988) Rot turnover in a beech and a spruce stand of the Belgian Ardenes. Plant Soil 105:87-104

Vanninen P, Ylitalo H, Sievänen R, Mäkelä A (1996) Effects of age and site quality on the distribution of biomass in Scots pine (Pinus sylvestris L.). Trees Struct Funct 10:231-238

Vogt KA (1991) Carbon budgets of temperate forest ecosystems. Tree Physiol 9:69-86

Vyskot M (1976) Tree story biomass in lowland forets in South Moravia. Rozpravy CSAV 86(10), 186, Academia Praha

Walter JMN, Grégoire-Himmler C (1996) Spatial heterogeneity of a Scots pine canopy: an assessment by hemispherical photographs. Can J For Res 26:1610-1619

Wang J, Zhang C, Xia F, Zhao X, Wu L, Gadow K (2011) Biomass structure and allometry of Abies nephrolepis (Maxim) in Northeast China. Silva Fenn 45:211-226

Waring RH, Whitehead D, Jarvis PG (1979) The contribution of stored water to transpiration in Scots pine. Plant, Cell Environ 2:309-317

Weiskittel AR, Maguire DA (2006) Branch surface area and its vertical distribution in coastal Douglas-fir. Tree Physiol 20:657-667

Xiao C-W, Curiel-Yuste J, Janssens IA, Roskams P, Nachtergale L, Carrara A, Yeste-Sanchez B, Ceulemans R (2003) Above- and belowground biomass and net primary production in a 73-yearold Scots pine forest. Tree Physiol 23:505-516

Younger NL, Temesgen H, Garber SM (2008) Taper and volume responses of Douglas-fir to sulfur treatments for control of Swiss needle cast in the coast range of Oregon. West J Appl For 23:142-148

Zimmerman MH (1983) Xylem structure and the ascent of sap. Springer, Berlin

Zweifel R, Item H, Häsler R (2000) Stem radius changes and their relation to stored water in stems of young Norway spruce trees. Trees 15:50-75 